\title{
FORMS OF INFORMALITY AND ADAPTATIONS IN INFORMAL SETTLEMENTS
}

\author{
Hesam Kamalipour \\ Faculty of Architecture, Building and Planning \\ University of Melbourne, Australia \\ hesam.kamalipour@unimelb.edu.au
}

\begin{abstract}
Informal settlements have become integral to the urban imagery of the cities across the global South. Forms of urban informality emerge and grow through some generative processes of self-organisation and incremental adaptations. While formal interventions have often failed to put an end to such a resilient and complex type of urbanism, the desire for eradication and demolishment still prevails. Most of the informal settlements can benefit from incremental upgrading and micro-scale design interventions, which then rely on a sophisticated understanding and analysis of informal morphologies and adaptations. However, forms of urban informality and adaptations of informal settlements are relatively understudied. This paper aims to explore informal morphologies and their incremental adaptations drawing on empirical evidence from the case study of Khlong Toei district in Bangkok (Thailand). Direct observation, visual recording, and urban mapping are the key research methods. Five different forms of informality and adaptations have been identified in this study. One of the findings of this study is that informal morphologies emerge in different forms at multiple scales. Another finding of this study is that informal adaptations are often similar across different informal morphologies. The findings of this paper contribute to the growing body of knowledge in urban morphology and informal urbanism.
\end{abstract}

Keywords: Urban morphology; incrementalism; typology; informal settlement; mapping

\section{INTRODUCTION}

Urban informality incorporates the activities that take place outside the control of the state (Dovey \& King, 2012; Roy \& AlSayyad, 2004). In this sense, informal urbanism is about the unauthorised and ordinary practices of city-making playing a key role in the ways in which the developing cities work (AISayyad, 2004; Bayat, 2000; Dovey, 2012; Simone, 2009; Tonkiss, 2013). The cities of the global South have experienced the process of rapid urbanisation, rural-urban migration, and the emergence of informal settlements over the last decades (Miraftab \& Kudva, 2014). It has been estimated that more than one billion people live in informal settlements across the globe (UN-HABITAT, 2006). Over the last two decades, there has been an emerging view that urban theory needs to incorporate some different geographies of knowledge to address the dynamics of rapid urbanisation and complexity of informal urbanism in the cities of the global South (Edensor \& Jayne, 2012; Parnell \& Robinson, 2012; Robinson, 2002; Roy, 2009; Roy \& AISayyad, 2004). Although informal settlements are generally off the official maps and socio-spatially undocumented (Patel \& Baptist, 2012; Robinson, 2002), it has been long argued that inhabitants of these settlements are by no means marginal to their cities (Perlman, 1976). Informal settlements are often the centres of ingenuity and creativity (Neuwirth, 2004; Roy, 2011). Although the critical role of micro-scale design interventions and analysis of informal morphologies has been recognised (Dovey \& King, 2011; Duarte, 2009; Marshall, 2009), forms of urban informality and adaptations of informal settlements are relatively understudied (Brillembourg \& Klumpner, 2010; Dovey, 2013, 2014). Drawing on empirical evidence from the city of Bangkok, this study aims to provide a better understanding of different forms and 
adaptations of informal settlements. Such an understanding is a key condition for unravelling the capacities of informal settlements through analysing the ways in which they work.

This study reports the findings from the case study of Khlong Toei district in the city of Bangkok. After a brief review of the literature and introducing the applied research methods, the first part of this paper investigates the ways in which formal and informal are related to each other at the macro scale through mapping pockets of urban informality against expansion layers of the city. The second part investigates different forms of urban informality focusing on the study area. Informal adaptations are explored in the third part at the neighbourhood scale. The last part is dedicated to the discussion of the results, limitations, and future lines of inquiry.

\section{INFORMAL FORMS AND ADAPTATIONS}

Typologies, morphologies, and adaptations of informal settlements are fairly underexplored in the literature. Developing typologies of informal settlements in a global context based on some spatial criteria has been a topic of a few studies. As it is often impossible to provide an accurate definition of urban informality (Gilbert, 2004), the term has been adopted differently within the past decades (Bunnell \& Harris, 2012). In effect, the criteria for developing typologies of informal settlements are not often the same. Davis (2006) suggests a typology of informal settlements based on proximity to job opportunities. This typology develops a framework for categorising informal settlements based on their location and formal/informal conditions. Dovey and King (2011) outline a typology of informal settlements taking into account the processes of growth in terms of settling, inserting or attaching. This typology introduces eight types framed within the categories of districts, interfaces, trajectories, and topographies. A typology of urban interfaces in informal settlements is also developed for mapping different public/private interfaces based on the criteria of proximity and connectivity to the public space (Kamalipour, 2016a). The developed typologies provide insights to the variations of informal morphologies in a global context.

Urban morphology has been a key area of research in urban design with a focus on form, time, and resolution (Moudon, 1997). Morphologies of informal settlements are generally explored at the micro scale focusing more on some formal rather than temporal aspects. It has been indicated that the access network in these settlements often follows the topographic conditions and the existing pathways (Arefi, 2011; Ribeiro, 1997). Bhatt and Rybczynski (2003) have identified several spaces including housing extensions, workplace, small shops, and streets with a focus on the role of trees, vehicles, and public structures in informal settlements. The relations between functional mix, accessibility, building density, street-life intensity, and public/private interfaces have been explored to provide a better understanding of the micro-scale informal morphologies (Kamalipour, 2016b). It has also been indicated how an informal structure can accommodate a mix of working and living (Kellett \& Tipple, 2000). A vertical mix of formal and informal has been documented to shed light on the ways in which informal morphologies emerge and grow within a formal structure (Brillembourg \& Klumpner, 2013). There is also a temporal dimension to informal morphologies, which is about the processes of incremental adaptations.

Forms of urban informality emerge and adapt over time through generative processes of change. Generative processes address the 'actions' need to be taken rather than the 'end-results' visualised in some detailed drawings (Hakim, 2007). Generative processes of self-organisation have been a topic of research in urban design theory (Alexander, 2002; Alexander, Ishikawa, \& Silverstein, 1977; Hakim, 2014; Jacobs, 1961; Mehaffy, 2008). Complex adaptive systems are unpredictable, dynamic, and non-linear (Hakim, 2008). Informal settlements have been considered as 'complex adaptive assemblages' (Dovey, 2012). Salingaros (2000) points out that the small scale often emerges before the large scale in informal settlements. Moreover, it has been long argued that informal settlements can be considered as 'modern vernacular environments' since they are both incremental and spontaneous (Lapping, 1973). As Hamdi (2004) argues, spontaneity and improvisation are integral to the incremental processes of 
change. While most of the studies on the self-organised morphologies have often focused on traditional settlements (H. Davis, 2006; Hakim, 2007, 2008, 2014; Kamalipour \& Zaroudi, 2014), incremental adaptations of informal settlements are relatively understudied. This study aims to explore not only different forms of informality at the city and neighbourhood scales but also dynamics of change at the micro scale using a case study method.

\section{RESEARCH METHODS}

This is a case-study research that aims to provide a better understanding of informal morphologies by exploring forms of urban informality and adaptations in the study area of Khlong Toei in Bangkok. The case study has been selected based on the criteria of accessibility to the researcher and data richness (Neuman, 2011). The selected case study includes data richness regarding different forms of urban informality that is critical for the aim of this study. Direct observation, visual recording, and urban mapping are the key research methods in this study (Peimani \& Kamalipour, 2016). As Habraken (1998) points out, direct observations are often more informative than interviewing the actors in urban environments for deducing patterns. While most of the required data on forms of urban informality and adaptations has been collected through direct observation by the researcher, urban photography has been used as a supplementary method to fill the gaps of observation and provide further details (Gehl \& Svarre, 2013). Urban mapping is used to unravel the ways in which different forms of urban informality work at the city and neighbourhood scales (Kamalipour \& Peimani, 2015). It has been argued that mapping has the capacity to unfold the unseen realities (Corner, 1999). Using QGIS and Google Earth, pockets of urban informality have been mapped at the city scale based on the criteria of spatial concentration, construction material, and access network.

\section{INFORMAL MORPHOLOGIES IN BANGKOK}

Bangkok is a flat water-based city that was established as the capital of Siam in the late 18th century within the eastern delta of the Chao Phraya River. The city was structured based on a network of khlongs (canals) as a water-based access network. The royal capital of Thailand has become one of the key commercial centres in Southeast Asia by the mid-20th century. As the city struggled with modernisation, many khlongs were replaced by roads. In this way, Bangkok has been transformed from the city of flowing ferries and barges along the khlongs to the city of traffic congestion with a large informal sector overlaid by a muddled display of the first world imagery (Dick \& Rimmer, 2003; King, 2011). Depending on the urban boundaries, the population of Bangkok varies from 6.5 to more than 10 million (Yap \& De Wandeler, 2010). It has been estimated that more than one million people live in informal settlements across the city (Kramer, 2006). 


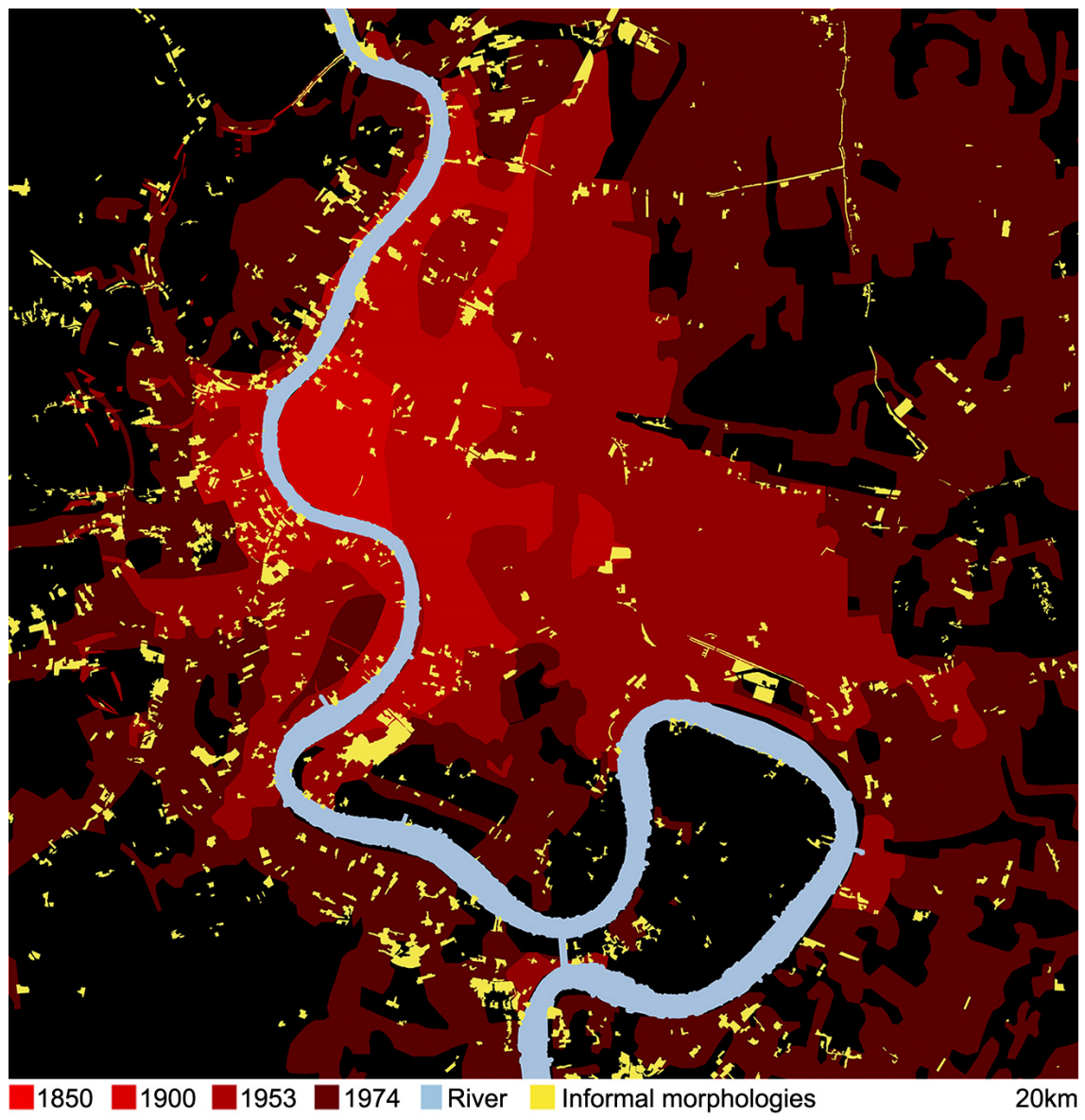

Figure 1. Pockets of urban informality in Bangkok

(Source: Author, with the historical layers based on Angel et al. 2011).

Pockets of urban informality have been mapped against the expansion layers of the city to explore the ways in which different informal settlements are located in relation to the formal city. Mapping these pockets is particularly problematic in the city of Bangkok where the visual boundaries between informal settlements and traditional khlongs are often ambiguous. Moreover, many patches of urban informality are too small to be mapped at the macro scale, and certain types of urban informality that are either attached to or contained within a formal structure (Dovey \& King, 2011) are often untraceable on the aerial photos. Figure 1 shows a broad distribution of informal settlements across the city with relatively few large pockets and a very large number of small ones. Most of the informal pockets are located in the western parts of the city in proximity to the Chao Phraya River. Many of the small settlements are located along some of the remaining khlongs. These settlements often form a linear pattern of growth along the waterways. Many of the other linear forms of urban informality take place along the railways. District is the other major form of informality where informal settlements are concentrated in proximity to the major religious nodes across the city (Askew, 2002). The emergence of these major forms of informality is linked to the availability of unoccupied land and low rental rate in proximity to the temples and khlongs (Wattanawanyoo, 2012). As Figure 1 indicates, only a few patches of urban informality are located within the first layer of expansion. This is the historic core of the city developed on the east bank of the Chao Phraya River as a fortified site. Rural-to-urban migrants started to occupy the underused land after the mid-20th century when both the state and the private sector could not provide affordable housing for the newcomers (Berner \& Korff, 1995). 


\section{FORMS OF URBAN INFORMALITY IN KHLONG TOEI}

As one of the largest pockets of urban informality, the history of Khlong Toei goes back to 1960s when job opportunities became available in proximity to the port of Khlong Toei (Berner \& Korff, 1995), which was the key node of the waterway transportations close to the Gulf of Thailand (Figure 2). The swampy land of the area has been encroached over time by the ones who worked in the area. Khlong Toei entails contrasting stories of reported crime and squalor on one hand, and community resistance and contributions of some charismatic figures to health and children education on the other hand (King, 2011). It has been estimated that about 25,000 informal inhabitants live on 325 acres of land, which mostly belongs to the Port Authority of Thailand (Askew, 2002). However, forms of tenure are not entirely legal or illegal (King \& Dovey, 2013).

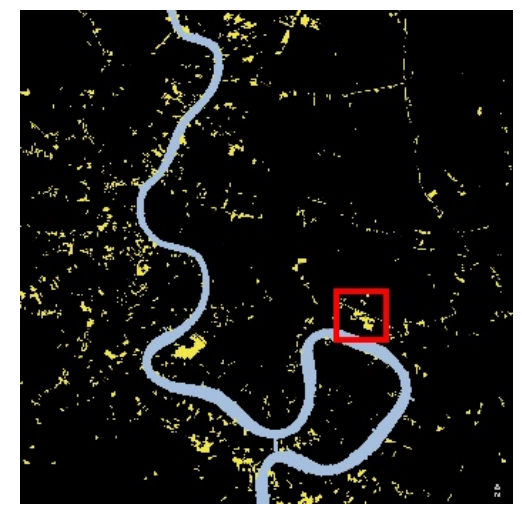

Figure 2. The study area of Khlong Toei in Bangkok (Source: Author).

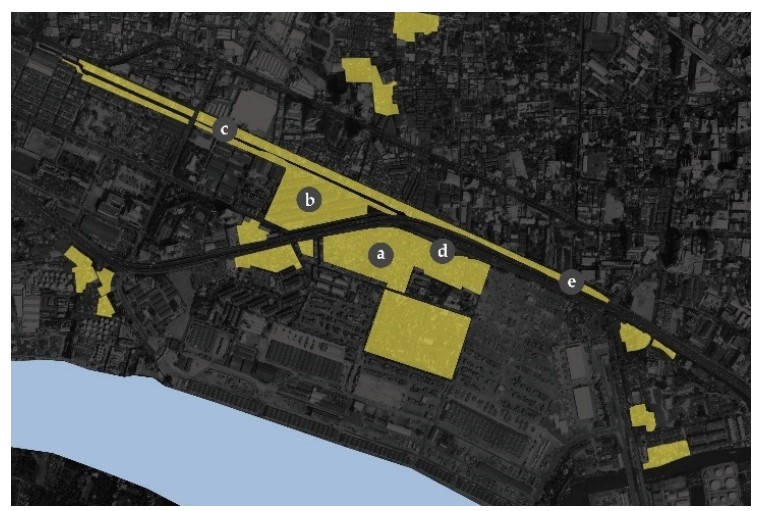

Figure 3. Location of the study areas in Khlong Toei (Source: Author based on Google Earth).

Pockets of urban informality have been mapped to show the locations and variations of the informal settlements in Khlong Toei. Figure 3 indicates that pockets of urban informality vary in terms of form, size, and location. There are two major types of informal morphologies in the study area that are linked to the general types of informal morphologies in the city of Bangkok. The first type forms a district of informal settlements (Figure 3.a) or a mix of formal and informal structures concentrated in a district (Figure 3.b). The second type of informal settlements forms a linear morphology that often emerges and grows along major urban infrastructures including khlongs (Figure 3.c), railways (Figure 3.d), and highways (Figure 3.e). In this way, five different forms of informality can be identified.

One of the dominant forms of urban informality in Khlong Toei is a relatively large district of informal settlements occupying an area of more than 10 hectares. Figure 4.a illustrates the ways in which the concentration of informal structures is hidden behind a relatively formal façade of mid-rise slabs. With more than 90 percent of gross coverage, the built area hardly exceeds more than two levels in height. This is a condition of high internal density and low-rise buildings. The area is predominantly residential with a mix of some local shops (Figure 4.b) and some community facilities. The access network forms a relatively regular grid (Figure 4.a) with several entrances located between the slabs (Figure 4.c).

Another district type in the study area is a formal insertion of a mid-rise housing compound that has been informalised over time. It includes 11 parallel five-storey slabs with the length of 80130 metres and width of 25 metres. Figure 5.a shows the ways in which urban informality plays out within the formal housing compound. The gross coverage is about 45 percent. Although the housing compound is monofunctional, some informal shops are located within the area. The access network within the compound is a combination of regular grid and cul-de-sacs. The housing compound is segregated from the surrounding area by more than 600 metres of blank 
walls. The main connection gateway is an entrance, which is located in the southern part of the compound (Figure 5.b). Due to the vertical development of the apartment slabs and allocation of the ground floor to parking, the ground floor is publicly accessible, yet mostly vacant (Figure 5.c). In a sense, the private realm and public space are vertically separated from each other in a way that the intricate relations between public and private interfaces are not likely to take place on the ground floor anymore.
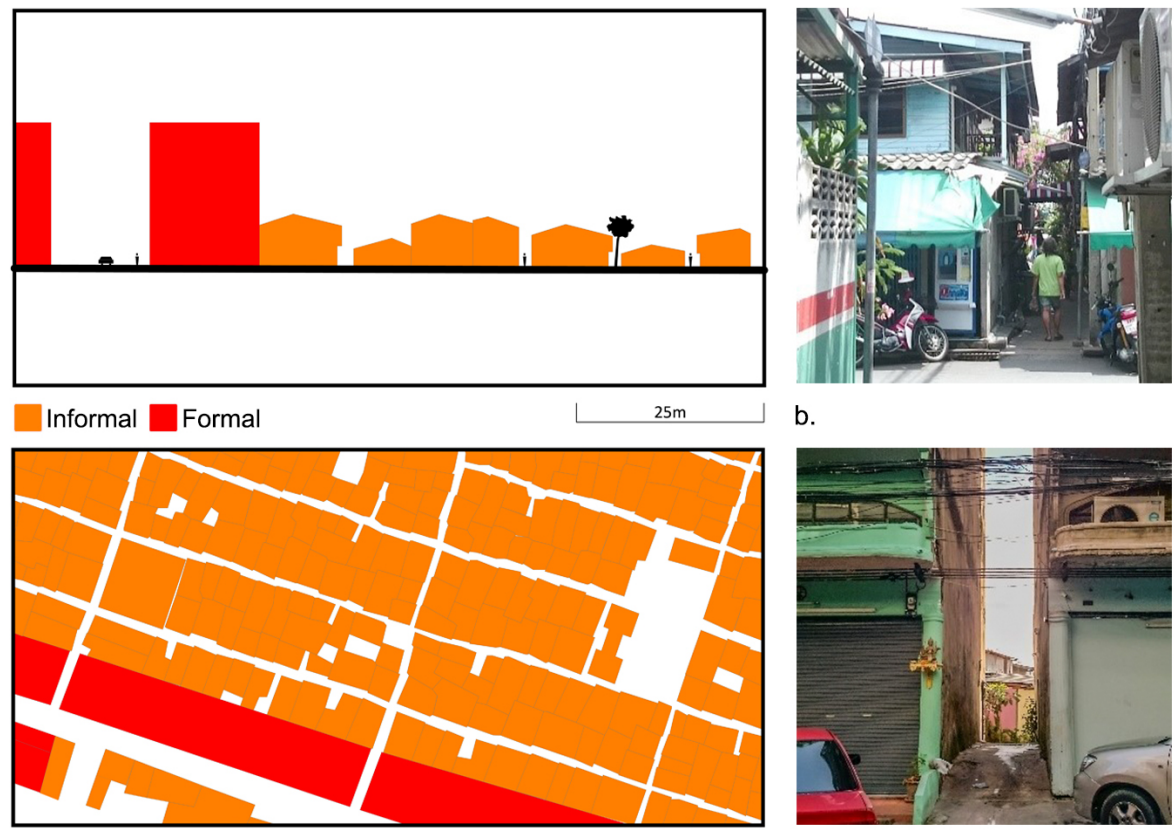

a.

c.

Figure 4. The concentration of informal structures in a district (Source: Author).
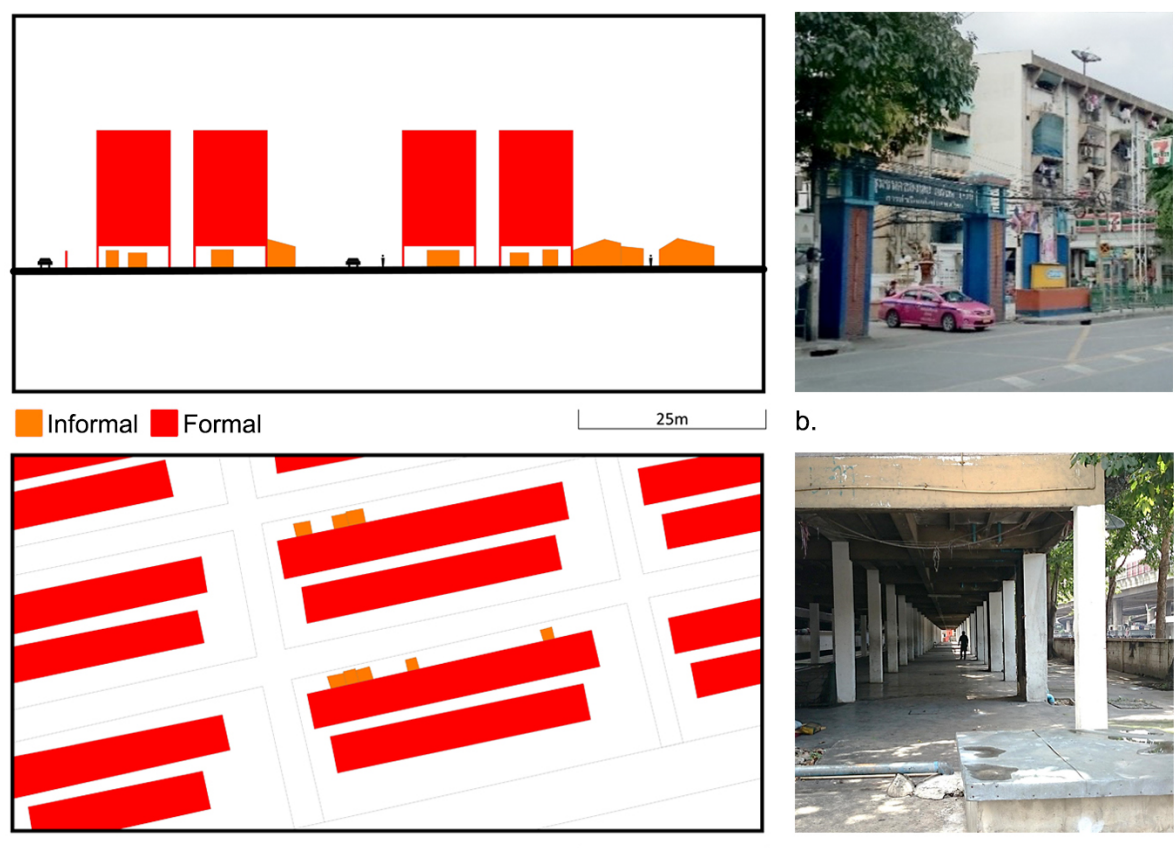

b.

a.

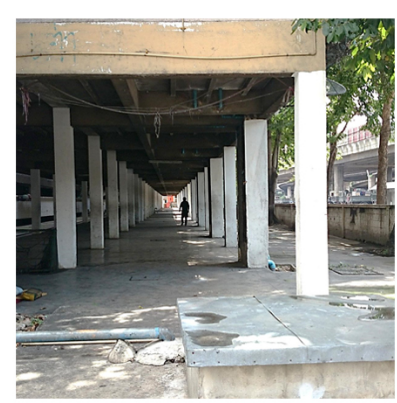

c.

Figure 5. A mix of formal and informal in an informalised housing compound

(Source: Author). 
One of the informal settlements that form a linear morphology is located along the khlong (Figure 6.a). This settlement follows two main patterns of access. The first pattern takes place where the khlong edge is appropriated by a strip of houses that block the public access to the khlong (Figure 6.a). In this case, pedestrian laneway is located at the back of the houses facing the khlong. Since a formal street is located in the northern part of the area, the pedestrian laneway is combined with vehicular access. The second pattern emerges wherever the public access comes between a strip of informal structures and the khlong (Figure 6.b). In effect, the khlong edge becomes publicly accessible from the same laneway that provides access to the houses that have emerged along the waterway. In this case, the average width of the pedestrian laneway ranges from 80 to 120 centimetres. However, this configuration changes when half-room extensions emerge over the khlong (Figure 6.b). As Figure 6.b shows, while the visual connectivity between the two sides of the khlong is slightly high, they are physically disconnected from each other. One should walk for more than $2 \mathrm{~km}$ in order to go from a house on one side of the khlong to another house across the khlong that are just $15 \mathrm{~m}$ far from each other. In a sense, while the housing strips along either side of the khlong are geometrically close to each other, they are topologically far from each other.

Building height ranges from one to two levels and second floors often extend over the pedestrian laneways, which block natural light and ventilation of the public laneway. The area is predominantly residential. However, one can find a vertical mix of a shop on the ground floor and residential units on the upper floors. That is how most of the shops are located along the northern housing strip, which fills the gap between the khlong and the street (Figure 6.c). In this way, facing a formal urban street provides the opportunity for the shops to become popular enough for attracting people from the adjacent neighbourhoods (Figure 6.c). On the other side of the khlong, a shop, which is located in the middle of the southern strip of informal structures provides the internet and online gaming services (Figure 6.d). In a way, it provides the possibility of getting connected to internet network and establishing social integration to the formal city for the inhabitants whose dwellings are physically segregated from the city.
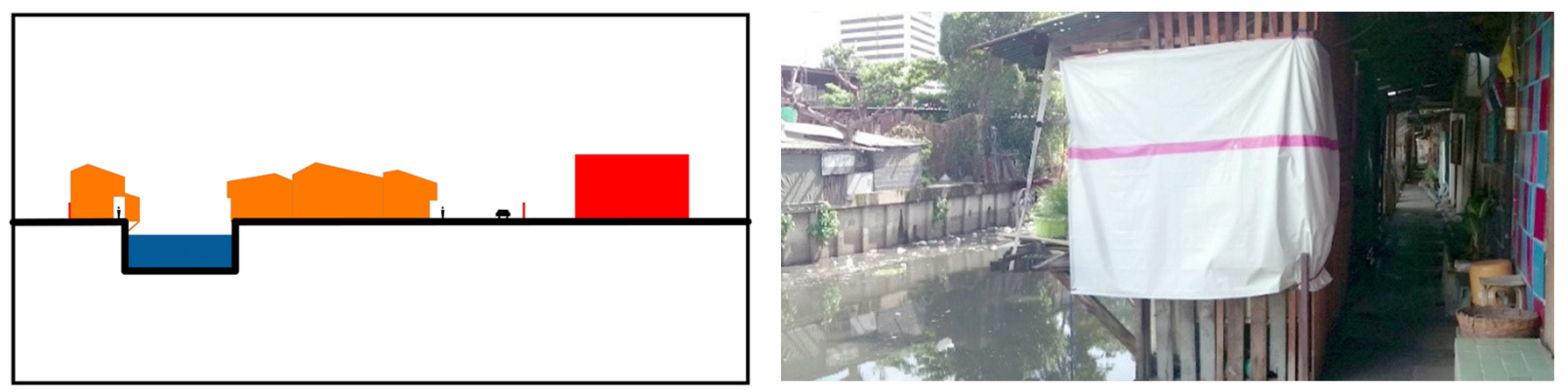

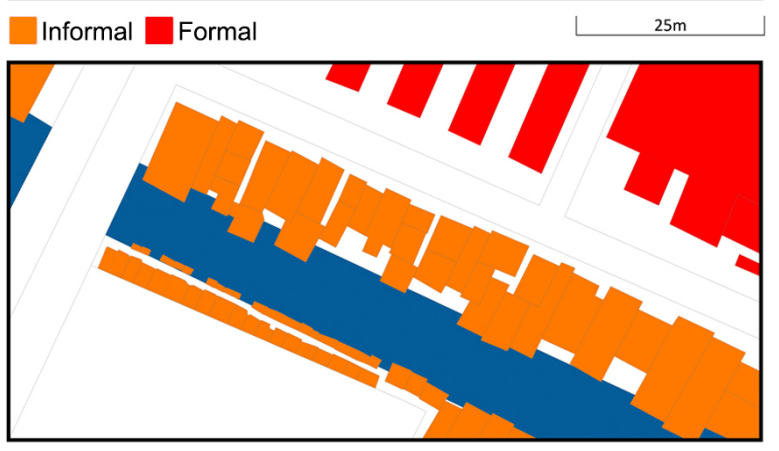

a.

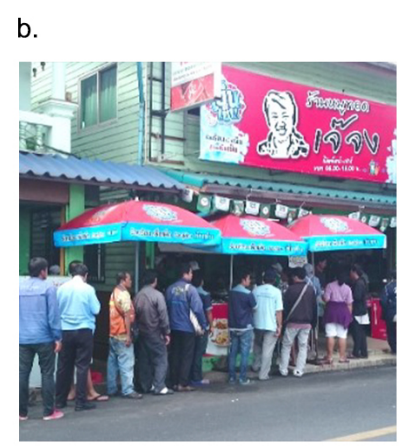

c.

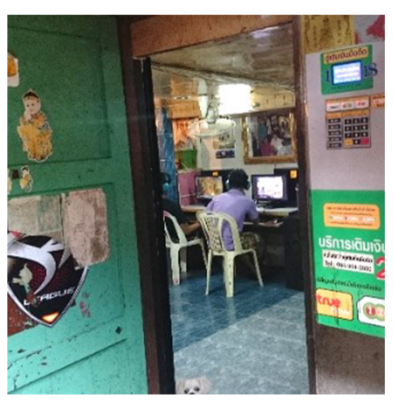

d.

Figure 6. The khlong-based settlement (Source: Author). 
The railway-based settlement is another linear type in the study area. Along the railway for less than a kilometre, an informal settlement has emerged in a way that a specific type of public space works on a temporary basis. The public space is located on the railway line in-between two strips of informal structures that have emerged along both sides of the railway (Figure 7.a). The functionality of the public space is related to the frequency of the trains passing through, which is limited to 2-3 times per day. The width of the public space is adapted to the width of a train. Daily activities are likely to take place on the railway whenever there is no train passing through.

The building height ranges from one to two storeys. The area is predominantly residential with a few local shops on either side of the railway. A strip of timber workshops occupies the first $300 \mathrm{~m}$ of the area to the east (Figure 7.b). This is the only part of the area where the northern side of the settlement faces a busy street with vehicular traffic. In effect, the timber workshops temporally appropriate a part of the street (up to 2.5 metres) to advertise the products made on the railway line (Figure 7.c). The overall access pattern of this type is linear with informal structures on both sides of the railway. While houses are aligned with each other and attached side-by-side, a few narrow laneways break through and connect the public laneway of the railway settlement to the adjacent access network of another district of informal settlements. The threshold (60 to 90 centimetres) between the public laneway and private space plays a key role in accommodating a range of activities including drying clothes, seating, socialising, parking bikes, storing furniture or materials, and growing plants (Figure 7.d). When the train comes in, everything is pushed back to the thresholds on both sides of the railway line (Figure 7.e).

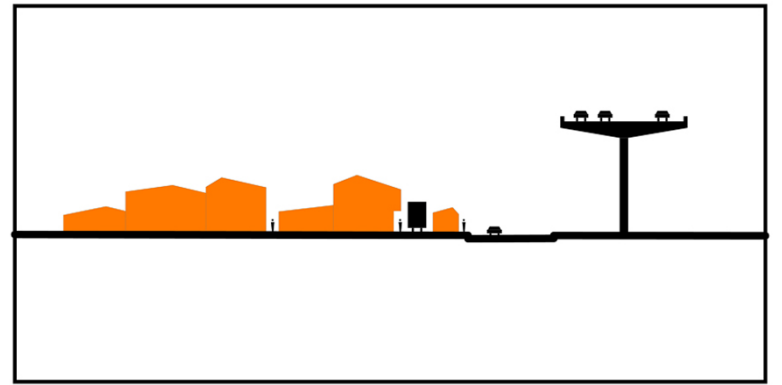

Informal $\square$ Formal

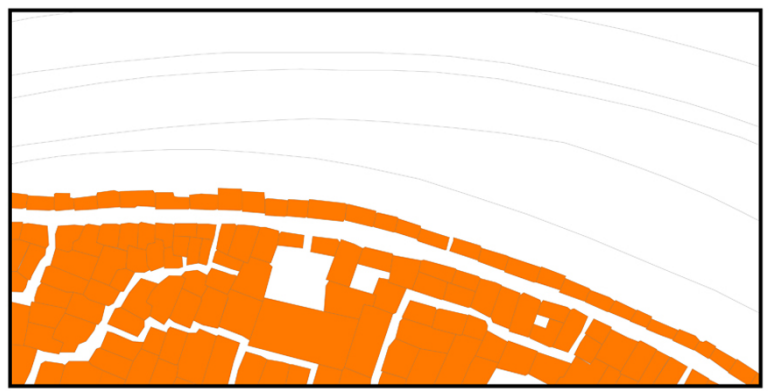

a.

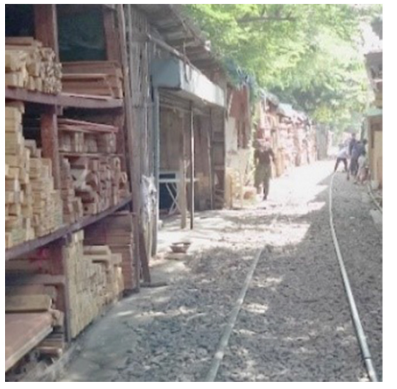

b.

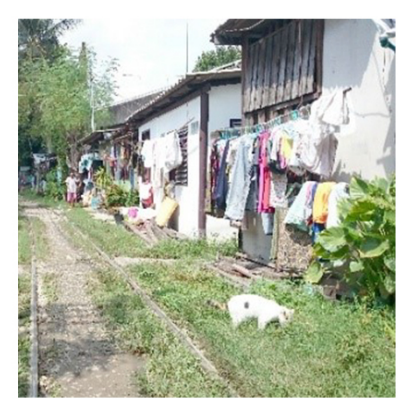

d.

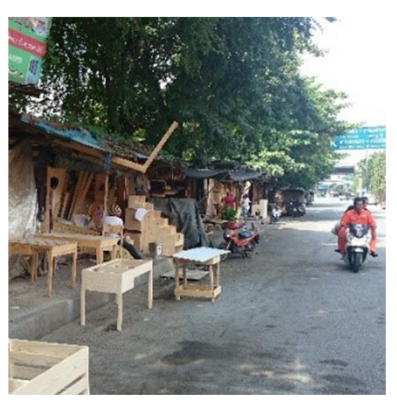

c.

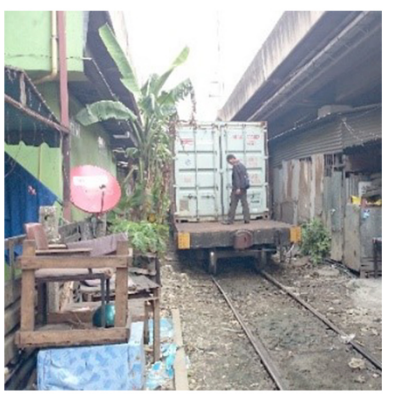

e.

Figure 7. The railway-based settlement (Source: Author).

Another linear type of informal settlements is located under the Chalerm Maha Nakhon Expressway in a way that a linear strip of informal structures fills the urban interstices between a formal street, a khlong, and an elevated expressway (Figure 8.a). In a sense, it fills the urban vacuum between the infrastructural elements of the formal city that resonates with the concept of 'terrain vague' (Solà-Morales, 1995). The informal settlement has emerged on one side of the khlong where the development of an elevated expressway has provided the possibility of further encroachments on the leftover spaces beneath. The street located on the northern side of the 
khlong and expressway has become a shared territory where the formal city is confronted with the informal settlement. In this way, only one side of the housing strip faces the public space, which is a formal street.

Building height ranges from one to two stories with a few three-story structures (Figure 8.b). At times, there are a few private open spaces facing the khlong. While the settlement is predominantly residential, several shops and workshops have been opened up where the informal structures face the formal street (Figure 8.c). Although the housing strip has both southern and northern façades, the whole settlement is merely accessible from the northern side where the formal street has been laid out. A threshold ranging from 60 to 150 centimetres accommodates different activities and loose parts including construction materials, small-scale temples, trolleys of informal traders, parked motorbikes, and attached advertisements (Figure 8.d). Storing domestic paraphernalia and drying clothes take place in the private open spaces facing the khlong. In this way, there is a distribution of loose parts on either side of the informal structures.

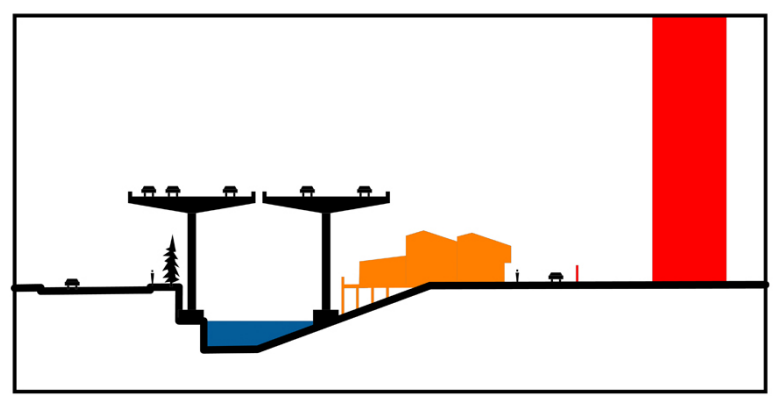

Informal $\square$ Formal

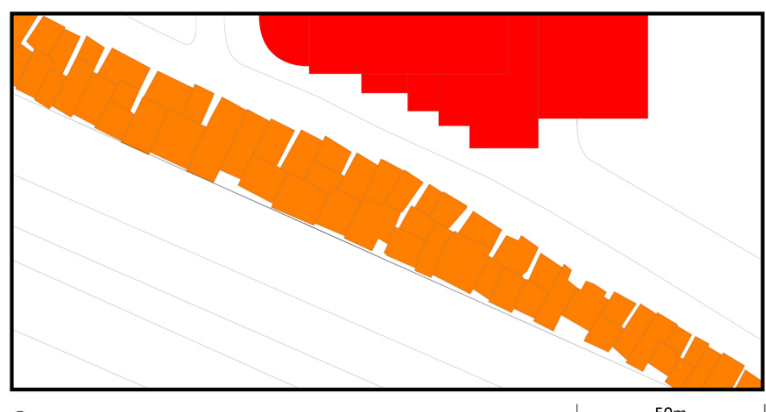

a.

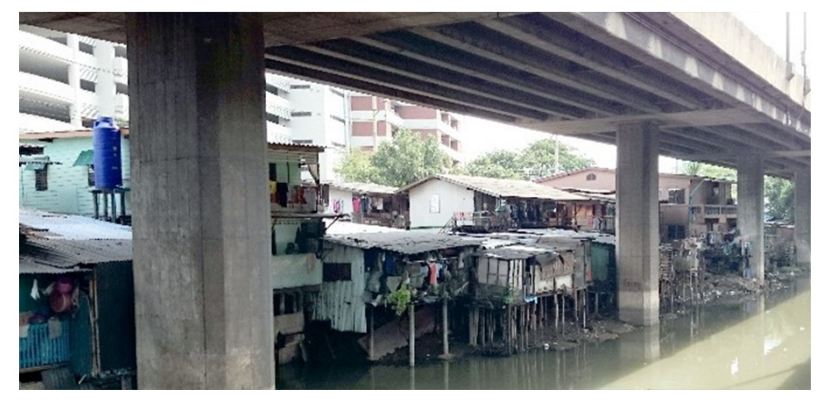

b.

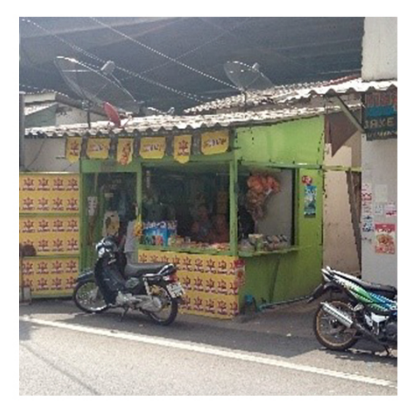

c.

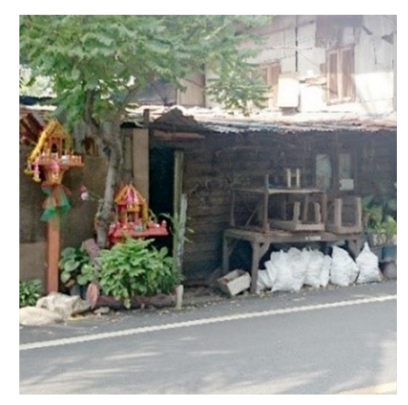

d.

Figure 8. The settlement under an elevated expressway (Source: Author).

\section{INFORMAL ADAPTATIONS IN KHLONG TOEI}

Informal adaptations and incremental transformations are integral to the generative processes of growth in informal settlements. This part explores the increments of change in different forms of urban informality in order to provide a better understanding of the ways in which adaptations play out in informal settlements. There are several forms of informal adaptations in the study area including room or multiple-room addition, material replacement, infill addition, extensions, and spatial division.

The room-by-room addition is a key adaptation, which often takes place in both linear and district types of the informal settlements. This adaptation happens when a part of the family income can be invested on adding a room to the house in order to provide an opportunity either for renting or for extending the living area. Although this increment is often accomplished overnight, it is reliant on the provision of the construction materials and local experts. At times, multiple rooms can be added in a one-go when the required resources are available. Depending 
on the availability of the land and the possibility of further encroachment on public space, a room or multiple rooms can be added either horizontally or vertically (Figure 9).

Material replacement is another form of adaptation, which generally aims for improving construction quality or repairing the previously utilised ones (Figure 10). The room/multiple-room addition is often accompanied with a change of material in informal structures. While replacing the construction materials is likely to be a part of the other increments like a room or multipleroom additions, it can also take place as a single increment of change. Replacing an old existing material with a new one or changing from a more temporary material to a more permanent one is space-neutral.

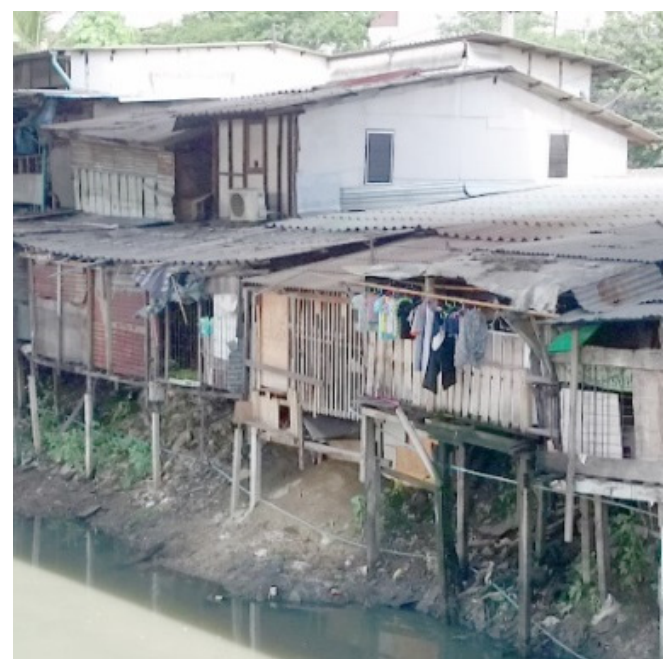

Figure 9. Adding room/multiple rooms (Source: Author).

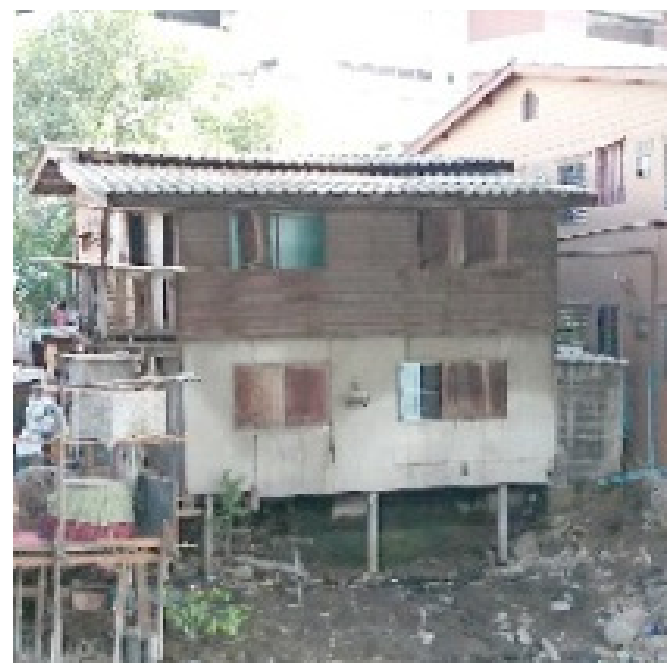

Figure 10. Changing the construction materials (Source: Author).

Another informal adaptation in the study area refers to the ways in which a formal building becomes informalised over time where urban informality emerges within or attaches to a formal structure as an infill. Insertion of a mid-rise housing compound is a transformational change, which is a part of a formal upgrading. While delivery of the housing compound can be considered as an end for transforming an informal settlement, it is a departure point for the incremental process of change. The ground level of the apartment blocks was supposed to provide the inhabitants with parking. However, an incremental process of change has been triggered for appropriating the leftover spaces at the ground level to reclaim the ways in which public/private interfaces used to work in informal settlements. While the apartment blocks are merely residential, the ground floor has been gradually appropriated to accommodate a range of different activities including shopping, playing, and socialising. Moreover, the ground floor has been appropriated in a way to be used mostly as a storage area (Figure 11.a). At times, one can also find a shop at the ground level that has been opened up in the parking area (Figure 11.b). Hence, this small-scale increment utilises a previously developed formal structure. In the same vein, another adaptation is about the emergence of a shopping strip on the northern part of the compound where the apartment slabs face the khlong. A roofed passageway with shops on both sides can be considered as an attempt for providing income and changing the mono-functionality of the housing compound (Figure 11.c). Moreover, the addition of some shops that are attached to the apartment blocks at the ground level is an informal extension to the formally developed slabs (Figure 11.d). In this way, such adaptations intersect with the tensions between the informal process of horizontal densification, which is often accompanied with street life intensity at the ground level and the formal production of vertical density in the form of a housing compound. 


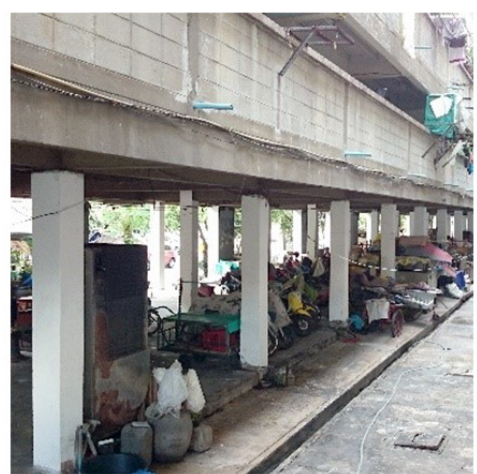

a.

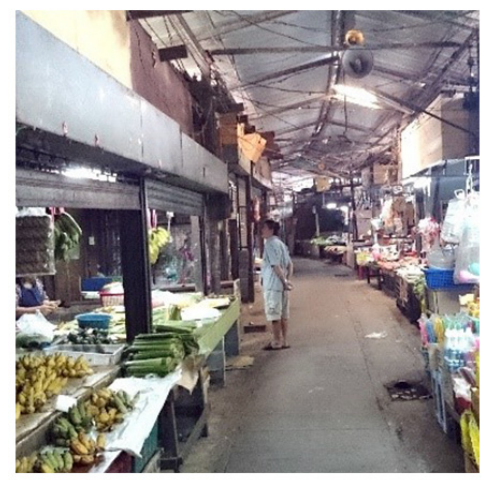

C.

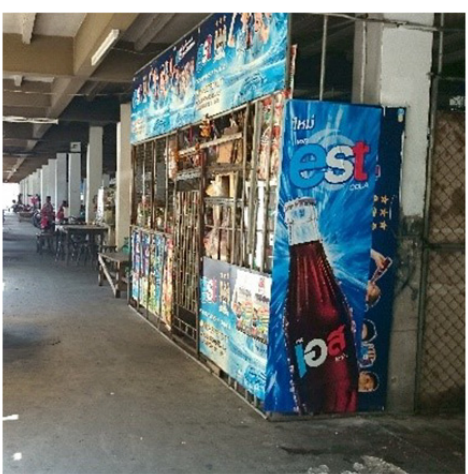

b.

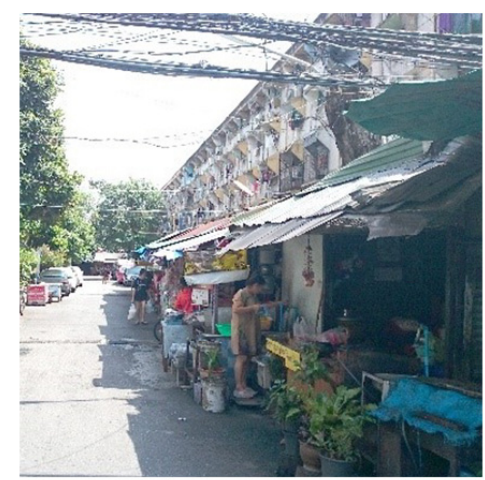

d.

Figure 11. Informalising a formal structure (Source: Author).

Other forms of adaptations take place when either an extension to a building or an internal space becomes divided to accommodate a mix of functions including residential and retail. The former adaptation is distinguishable when dwellers decide to extend their living area by adding balconies or verandas (Figure 12). While this increment might take place as a step before roomby-room addition, it can also be categorised as a separate adaptation on its own. This small-scale change can be compared with the other one, which aims to divide an internal space or change the functionality and public/private interface of a room at the ground level. Opening up a shop can be an example of changing room to a shop that can transform the ways in which public realm is connected to private space (Figure 13). Unlike the addition of balconies or verandas, the change of public/private interfaces does not add floor area to the informal structures.

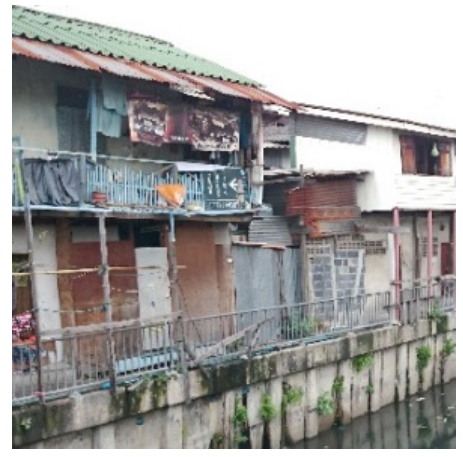

Figure 12. Adding balconies (Source: Author).

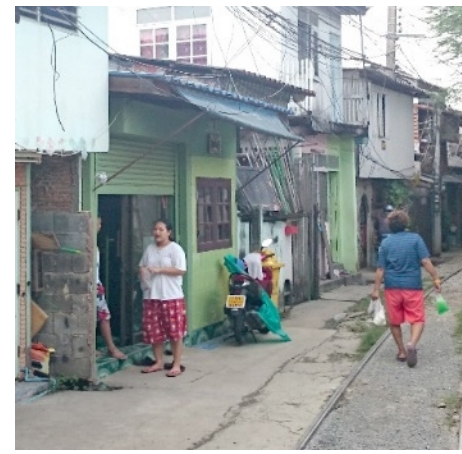

Figure 13. Opening up a shop (Source: Author). 


\section{DISCUSSION AND CONCLUSION}

Forms of urban informality and adaptations of informal settlements have been investigated drawing on evidence from the city of Bangkok. Urban mapping has been used as one of the key methods for exploring informal morphologies at the city scale and unravelling the relations between formal and informal at the neighborhood scale. Five different forms of informality and adaptations have been identified in this study. One of the key findings of this study is that informal morphologies emerge in different forms at multiple scales. Another key finding of this study is that incremental adaptations are often similar across different informal morphologies.

Exploring the spatiality of informal morphologies has the capacity to provide a better understanding of the relations between formal and informal at different scales. The results of the study suggest that although informal morphologies may appear as random and chaotic, there is often an underlying logic to the emergence and growth of various forms of informality. At the city scale, Informal morphologies are found to be different in size and form. Proximity to job opportunities and availability of some underused land have generally provided the spatial possibility for the emergence of informal settlements in the city of Bangkok. Congruent with previous studies (Askew, 2002; Wattanawanyoo, 2012), most of the informal morphologies are found to be located in proximity to some religious centres, waterways, and urban infrastructures. Most of the inhabitants of informal settlements have come to the city in pursuit of job opportunities rather than housing. As Davis (2006) points out, proximity to a job is often more critical than a shelter. This is a key for understanding why displacement of informal settlements to the urban fringes often fails as it does not take into account the intricate live-work relations. At the neighbourhood scale, as the results of this study show, different informal morphologies have emerged and evolved incrementally over time. Forms of urban informality are found to include the concentration of informal structures in a district; mix of formal and informal in an informalised housing compound, and linear morphologies emerged along some urban infrastructures such as khlong, railway, and expressway. The point here is that the explored informal morphologies often incorporate more than one of the types developed by Dovey and King (2011). For example, the concentration of informal structures is a combination of the 'district' and 'backstage' types. Similarly, the linear morphologies often embody a mix of 'waterfront' and 'easement' types. The spatial analysis of informal morphologies indicates how different forms of urban informality fill what Solà-Morales (1995) calls 'terrain vague' as the urban interstices and vacuums of the city.

Analysing the informal adaptations unravels how different forms of urban informality are continuously in the process of incremental change. Informal adaptations are found to be often similar across the studied forms of informality. The results of this study identify several increments of change including room or multiple-room addition, material replacement, infill addition, extensions, and spatial division. The point here is that informal morphologies emerge and adapt through generative processes of self-organisation. The concept of 'self-organisation' is central to complex systems (Portugali, 1997) where some unpredictable, dynamic, and different results are produced (Hakim, 2008). This may explain why different forms of urban informality often appear as some unfinished morphologies continuously made, unmade, and remade over time. As the results of this study show, even the insertion of a formal mass housing scheme is unable to put an end to the process of self-organisation and incremental adaptation over time. Urban morphologies, in this sense, incorporate a horizontal/vertical mix of formal and informal morphologies. The point here is that incrementalism is found to be integral to informal morphologies, which may explain why defining urban informality is not only socio-politically challenging but also spatially problematic. Much can be also learnt from exploring the incremental processes of change to understand the ways in which urban environments, as Dovey (2011) points out, incorporate a mix of both formal and informal conditions. Such an understanding raises questions about the capacities of the built environment professions to enable or constrain the processes of self-organisation and incremental adaptations. 


\section{LIMITATIONS AND FUTURE RESEARCH}

One of the findings of this study is to identify some limitations to consider in the spatial analysis of informal settlements. Accessible, accurate, and up-to-date data is critical for exploring the informal morphologies. Informal settlements are generally undocumented and off the formal maps (Patel \& Baptist, 2012; Robinson, 2002). Moreover, urban informality is a slippery concept, which often makes the process of mapping quite challenging. There is no claim here to be accurate and comprehensive in mapping informal morphologies at different scales. At the macro scale, the mapped pockets of informal morphologies are similarly presented although they may vary in terms of spatial structure. At the micro scale, mapping the distinction between formal and informal is also problematic, as some in-between conditions cannot be accurately mapped. Some of these limitations can be addressed in the future studies.

This study has explored different forms of urban informality and adaptations in the city of Bangkok. The micro-scale analysis of informal morphologies will be a topic of future studies to explore the relations between density, accessibility, diversity, and urban interfaces in informal settlements. Future researches can also contribute more case studies from different cities of the global South. Moreover, comparative analysis of different case studies of informal morphologies can reveal some commonalities and differences in terms of both the processes and forms of urban informality in a global context. While some informal adaptations have been identified in this study, investigating the ways in which incrementalism works through informal codes will also be a topic of future studies in this field.

\section{ACKNOWLEDGEMENTS}

The author receives IPRS and APA scholarships from the Australian Government. The author wishes to thank the anonymous reviewers for their time, incisive critique, encouragements, and helpful suggestions.

\section{REFERENCES}

Alexander, C. (2002). The process of creating life: an essay on the art of building and the nature of the universe. Berkeley, CA: Center for Environmental Structure.

Alexander, C., Ishikawa, S., \& Silverstein, M. (1977). A pattern language: towns, buildings, construction. New York: Oxford University Press.

AISayyad, N. (2004). Urban Informality as a "New" Way of Life. In A. Roy \& N. AlSayyad (Eds.), Urban informality: Transnational perspectives from the Middle East, Latin America, and South Asia (pp. 730). New York: Lexington.

Angel, S., Parent, J., Civco, D. L., Blei, A., \& Potere, D. (2011). The dimensions of global urban expansion: Estimates and projections for all countries, 2000-2050. Progress in Planning, 75(2), 53-107. http://doi.org/http://dx.doi.org/10.1016/j.progress.2011.04.001

Arefi, M. (2011). Order in Informal Settlements: A Case Study of Pinar, Istanbul. Built Environment, 37(1), $42-56$.

Askew, M. (2002). Bangkok, place, practice and representation. London: Routledge.

Bayat, A. (2000). From "Dangerous Classes" to "Quiet Rebels": Politics of the Urban Subaltern in the Global South. International Sociology, 15(3), 533-557. http://doi.org/10.1177/026858000015003005

Berner, E., \& Korff, R. (1995). Globalization and Local Resistance: The Creation of Localities in Manila and Bangkok. International Journal of Urban and Regional Research, 19(2), 208-222. http://doi.org/10.1111/j.1468-2427.1995.tb00501.x

Bhatt, V., \& Rybczynski, W. (2003). How the other half builds. In D. Watson, A. J. Plattus, \& R. G. Shibley (Eds.), Time-saver Standards in Urban Design (p. 1.3.1-1.3.12). New York: McGraw-Hill.

Brillembourg, A., \& Klumpner, H. (2010). Rules of engagement: Caracas and the informal city. In F. Hernández, P. Kellett, \& L. K. Allen (Eds.), Rethinking the informal city: critical perspectives from Latin America (pp. 119-136). New York: Berghahn Books.

Brillembourg, A., \& Klumpner, H. (Eds.). (2013). Torre David: informal vertical communities. Zurich, Switzerland: Lars Muller. 
Bunnell, T., \& Harris, A. (2012). Re-viewing informality: perspectives from urban Asia. International Development Planning Review, 34(4), 339-348. http://doi.org/10.3828/idpr.2012.21

Corner, J. (1999). The agency of mapping: Speculation, critique and invention. In D. Cosgrove (Ed.), Mappings (pp. 213-252). London: Reaktion Books.

Davis, H. (2006). The culture of building. New York: Oxford University Press.

Davis, M. (2006). Planet of slums. London: Verso.

Dick, H. W., \& Rimmer, P. J. (2003). Cities, transport, and communications: the integration of Southeast Asia since 1850. New York: Palgrave Macmillan.

Dovey, K. (2011). Uprooting critical urbanism. City, 15(3-4), 347-354. http://doi.org/10.1080/13604813.2011.595109

Dovey, K. (2012). Informal urbanism and complex adaptive assemblage. International Development Planning Review, 34(4), 349-367. http://doi.org/10.3828/idpr.2012.23

Dovey, K. (2013). Informalising Architecture: The Challenge of Informal Settlements. Architectural Design, 83(6), 82-89. http://doi.org/10.1002/ad.1679

Dovey, K. (2014). Incremental Urbanism: The Emergence of Informal Settlements. In T. Haas \& K. Olsson (Eds.), Emergent Urbanism: Urban Planning \& Design in Times of Structural and Systemic Change (pp. 45-53). Burlington, USA: Ashgate.

Dovey, K., \& King, R. (2011). Forms of informality: morphology and visibility of informal settlements. Built Environment, 37(1), 11-29.

Dovey, K., \& King, R. (2012). Informal Urbanism and the Taste for Slums. Tourism Geographies, 14(2), 275-293. http://doi.org/10.1080/14616688.2011.613944

Duarte, P. G. B. (2009). Informal settlements: A neglected aspect of morphological analysis. Urban Morphology, 13(2), 138-139.

Edensor, T., \& Jayne, M. (Eds.). (2012). Urban theory beyond the West: A world of cities. London: Routledge.

Gehl, J., \& Svarre, B. (2013). How to study public life. (K. A. Steenhard, Trans.). Washington, DC: Island Press.

Gilbert, A. (2004). Love in the Time of Enhanced Capital Flows: Reflections on the Links between Liberalization and Informality. In A. Roy \& N. AlSayyad (Eds.), Urban informality: Transnational perspectives from the Middle East, Latin America, and South Asia (pp. 33-66). New York: Lexington.

Habraken, N. J. (1998). The structure of the ordinary: form and control in the built environment. (J. Teicher, Ed.). Cambridge, Mass.: MIT Press.

Hakim, B. S. (2007). Generative processes for revitalizing historic towns or heritage districts. Urban Design International, 12(2), 87-99.

Hakim, B. S. (2008). Mediterranean urban and building codes: origins, content, impact, and lessons. Urban Design International, 13(1), 21-40.

Hakim, B. S. (2014). Mediterranean Urbanism: Historic Urban/Building Rules and Processes. New York: Springer.

Hamdi, N. (2004). Small change: about the art of practice and the limits of planning in cities. London: Earthscan.

Jacobs, J. (1961). The death and life of great American cities. New York: Random House.

Kamalipour, H. (2016a). Mapping Urban Interfaces: A Typology of Public/Private Interfaces in Informal Settlements. Spaces \& Flows: An International Journal of Urban \& Extra Urban Studies, in press.

Kamalipour, H. (2016b). Urban Morphologies in Informal Settlements. Contour, 3: Agency/Agents of Urbanity, in press.

Kamalipour, H., \& Peimani, N. (2015). Assemblage Thinking and the City: Implications for Urban Studies. Current Urban Studies, 3(4), 402-408. http://doi.org/10.4236/cus.2015.34031

Kamalipour, H., \& Zaroudi, M. (2014). Sociocultural Context and Vernacular Housing Morphology: A Case Study. Current Urban Studies, 2(3), 220-232. http://doi.org/10.4236/cus.2014.23022

Kellett, P., \& Tipple, A. G. (2000). The home as workplace: a study of income-generating activities within the domestic setting. Environment and Urbanization, 12(1), 203-214. http://doi.org/10.1177/095624780001200115

King, R. (2011). Reading Bangkok. Singapore: NUS Press.

King, R., \& Dovey, K. (2013). Active interstices. In A. M. Brighenti (Ed.), Urban Interstices: The Aesthetics and the Politics of the In-between (pp. 183-203). Burlington, VT: Ashgate. 
Kramer, M. (2006). Dispossessed: life in our world's urban slums. Maryknoll, NY: Orbis Books.

Lapping, M. B. (1973). Vernacular Environments: The Squatter Settlements. The Journal of Popular Culture, 7(2), 446-450. http://doi.org/10.1111/j.0022-3840.1973.0702_446.x

Marshall, S. (2009). Cities, Design \& Evolution. London; New York: Routledge.

Mehaffy, M. W. (2008). Generative methods in urban design: a progress assessment. Journal of Urbanism: International Research on Placemaking and Urban Sustainability, 1(1), 57-75. http://doi.org/10.1080/17549170801903678

Miraftab, F., \& Kudva, N. (2014). Introduction. In F. Miraftab \& Kudva (Eds.), Cities of the Global South Reader (pp. 1-6). Hoboken: Taylor and Francis.

Moudon, A. V. (1997). Urban morphology as an emerging interdisciplinary field. Urban Morphology, 1, 310.

Neuman, W. L. (2011). Social research methods: qualitative and quantitative approaches (7th ed.). Boston, Mass.: Pearson.

Neuwirth, R. (2004). Shadow cities: a billion squatters, a new urban world. New York: Routledge.

Parnell, S., \& Robinson, J. (2012). (Re)theorizing Cities from the Global South: Looking Beyond Neoliberalism. Urban Geography, 33(4), 593-617. http://doi.org/10.2747/0272-3638.33.4.593

Patel, S., \& Baptist, C. (2012). Editorial: Documenting by the undocumented. Environment and Urbanization, 24(1), 3-12. http://doi.org/10.1177/0956247812438364

Peimani, N., \& Kamalipour, H. (2016). Where Gender Comes to the Fore: Mapping Gender Mix in Urban Public Spaces. Spaces \& Flows: An International Journal of Urban \& Extra Urban Studies, 8(1), 1930.

Perlman, J. E. (1976). The Myth of Marginality: Urban Poverty and Politics in Rio de Janeiro. Berkeley, CA: University of California Press.

Portugali, J. (1997). Self-organizing cities. Futures, 29(4-5), 353-380. http://doi.org/http://dx.doi.org/10.1016/S0016-3287(97)00022-0

Ribeiro, G. (1997). An ecological approach to the study of urban spaces: the case of a shantytown in Brasilia. Journal of Architectural and Planning Research, 14(4), 289-300.

Robinson, J. (2002). Global and world cities: a view from off the map. International Journal of Urban and Regional Research, 26(3), 531-554. http://doi.org/10.1111/1468-2427.00397

Roy, A. (2009). The 21st-Century Metropolis: New Geographies of Theory. Regional Studies, 43(6), 819830. http://doi.org/10.1080/00343400701809665

Roy, A. (2011). Slumdog Cities: Rethinking Subaltern Urbanism. International Journal of Urban and Regional Research, 35(2), 223-238. http://doi.org/10.1111/j.1468-2427.2011.01051.x

Roy, A., \& AISayyad, N. (2004). Urban informality: Transnational perspectives from the Middle East, Latin America, and South Asia. New York: Lexington.

Salingaros, N. A. (2000). Complexity and Urban Coherence. Journal of Urban Design, 5(3), 291-316. http://doi.org/10.1080/713683969

Simone, A. (2009). City life from Jakarta to Dakar: movements at the crossroads. New York: Routledge.

Solà-Morales, I. (1995). Terrain vague. In C. Davidson (Ed.), Anyplace (pp. 118-123). Cambridge, MA: MIT Press.

Tonkiss, F. (2013). Cities by design: the social life of urban form. Cambridge: Polity.

UN-HABITAT. (2006). The state of the world's cities report 2006/7: The Millennium Development Goals and urban sustainability. London: Earthscan.

Wattanawanyoo, K. (2012). Poverty tourism as advocacy: a case in Bangkok. In F. Frenzel, K. Koens, \& M. Steinbrink (Eds.), Slum tourism: Poverty, power and ethics (Vol. 32, pp. 207-214). London: Routledge.

Yap, K. S., \& De Wandeler, K. (2010). Self-help housing in Bangkok. Habitat International, 34(3), 332-341. http://doi.org/http://dx.doi.org/10.1016/j.habitatint.2009.11.006 


\section{ArchNet}

\section{AUTHOR}

\section{Hesam Kamalipour}

PhD Candidate

Faculty of Architecture, Building and Planning

Doctoral Academy Member

Melbourne Social Equity Institute

University of Melbourne,

hesam.kamalipour@unimelb.edu.au 